\title{
Revolution in the Town Halls: The Formation of Czechoslovakia, the Battle for the Town Halls and Power Transition in the Municipal Authorities of Moravian Towns after 1918
}

Petr Popelka*

vol. 10, 2021, 2, pp. 55-85

DOI: https://doi.org/10.33542/CAH2021-2-03

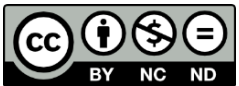

The study deals with the process of a power transition in Moravian nationally mixed towns after the First World War. The formation of Czechoslovakia was accompanied not only by the takeover of central political authorities, but necessarily also by a power transition at the regional level. The study takes particular note of the complicated process of the taking control of municipal councils in key Moravian towns, which were, until the formation of Czechoslovakia, in most cases under the decisive influence of the German bourgeoisie. Unlike in the Austro-Hungarian era, when the question of the composition of self-governments had been entirely in the hands of the local voters, the interest of the central institutions of the new state as well as of the political parties was now reflected in municipal affairs. In the process of the power transfer, the merging of municipalities played a very important role, being carried out in the post-war reality to serve as a means of solving the complex national-political situation in nationally mixed areas.

Keywords: Czechoslovakia. Czechoslovak towns. Moravia. Power transition. Municipal authorities. Merging of municipalities. Brno. Olomouc. Ostrava. Jihlava. Zábřeh. Czech-German relationships.

\section{Introduction}

In late 1918, people from all regions of the former Austria-Hungary experienced the joint trauma of the breakdown of the basic certainties of life. At the same time, the complex system of communication between the centre of the empire and the individual lands collapsed. However, the crumbling monarchy did not simply split into ready-made nation states. In fact, what emerged in October 1918 was something closer to a conglomerate of individual regions, in which the various national communities had different ideas about their future direction. ${ }^{1}$ The question of the existence and form of the successor states was therefore far from being a question regarding just the central political bodies and international negotiations, but had a significant regional dimension. This was more than clearly manifested in 1918 in the Bohemian Lands, primarily in ethnically mixed areas and in areas inhabited by the German ethnic group.

The topic of the power transition in the Central European area at the end of the First World War has been rightly popular for a century already. No wonder. In fact, for all authors, however they view the disintegration of centuries-old monarchies after

This study was created as part of the project SGS02/FF/2020-2021 "Československá společnost v meziválečném období: kontinuita, transformace, profesionalizace II.", carried out at the Faculty of Arts of the University of Ostrava.

Doc. PhDr. Petr Popelka, Ph.D., Department of History, Faculty of Arts, University of Ostrava, Czech Republic; petr.popelka@osu.cz; ORCID iD: 0000-0002-4504-8580

1 JUDSON, Welcher Zerfall? Welcher Triumph? 15-26. 
the First World War, 1918 is a crucial historical milestone. This milestone is linked to the whole thematic complex, primarily to the "great history" of the break-up of Austria-Hungary and its causes, the formation of the successor states, the analysis of the new geopolitical order and international relations, the rigmarole in the sphere of the complicated national relations among the new successor states, their internal order and questions regarding the impact on culture, everyday life and economic life. Nowadays, there is a seemingly infinite quantity of remarkable literature concerning all these facts, both of an analytical and synthetizing character. The periodically repeating jubilees of 1918 apparently intensify the above-mentioned interest, not only on the Czech side, but also in other Central European countries. ${ }^{2}$

In contemporary Czech historiography, the topic of the power transition in the administrative structures of the emerging state is quite an attractive one. ${ }^{3}$ The takeover of the state authorities took place in virtually all instances in several waves from the October events of 1918 until late 1919, and its characteristics and model cases are now described in at least their basic features. This is, however, different in the case of self-governing bodies, which had, for quite a long time, stood apart from the attention of researchers, and where we are still reliant on only a few case studies. ${ }^{4}$ The takeover of the municipal authorities, which, unlike the state authorities, were based on the principle of elections, was complicated in many ways, especially in key towns and residential agglomerations. However, the political bodies of the nascent state had a vested interest in securing the situation, especially in those areas where the Czech ethnic group was not in a dominant position, which was impossible without controlling the self-governing bodies. Moreover, the importance of the local elites grew in the long term and was even further strengthened by the collapse of the administrative structures in 1918.5

\section{The aim of the study and the characteristics of the surveyed towns}

The aim of the submitted study is to capture the power transition that started in 1918 in five strategically important Moravian municipal authorities. The study intends to reveal the strategies that were used to bring about the power transition and to shed light on the specifics of this process with regard to the diverse urban locations. ${ }^{6}$ In all cases, it is not only the application of the amendment to the election rules, which introduced universal, direct and equal suffrage, but also the amendment to the municipal constitution that appears to be crucial in relation to self-governments. This gave the government the ability to merge and divide municipalities, which, together with the suspension of the original municipal committees and their replacement by administrative commissioners, proved to be one of the important tools for controlling town halls in ethnically mixed areas. It is precisely the circumstances of the new battle for important town halls and the role of municipality mergers in this process

2 KOELTZSCH - KONRÁD, From "Islands of Democracy", 285-327. PEŠEK, Vznik, charakter a konec, 659-692. RUMPLER - HARMAT, Die Habsburgermonarchie 1848-1918.

3 KLEČACKÝ, Převzetí moci, 693-732. VYSKOČIL, C. k. úředník v československých službách, 425-459. KRLÍN, Výměny úředníků státní správy, 210-253. SCHELLE, Vznik Československé republiky, 5-42. ŠEDIVÝ, K otázce kontinuity nositelů státní moci, 189-196.

4 KONTNY, Herrschaftssicherung an der Peripherie, 381-405. POPELKA, Mocenský transfer, 87-111. POKLUDOVÁ, Änderung in der Stadtverwaltung, 87-112. MORELON, State Legitimacy, 43-63.

5 COHEN, Nationalist Politics, 441-478.

6 See: EGRY, Negotiating Post-Imperial Transitions, 15-42. 
that the study follows. In other words, it seeks to answer the basic question: was the wave of municipality mergers that took place in the early years of the existence of Czechoslovakia motivated by practical economic, transport and administrative reasons (which were the usual justifications), or were the reasons primarily national and political?

Now for a brief characterization of the monitored towns:

Brno/Brünn and Olomouc/Olmütz are two key Moravian statutory towns. As of 1910, more than 125,000 inhabitants lived in Brno, the land capital and the seat of important administrative institutions as well as an industrial centre. According to the census, for approximately $33 \%$ of these inhabitants the language of daily use was Czech. Olomouc was only sixth in terms of population in Moravia (after Brno, Moravská Ostrava, Prostějov, Jihlava and Vítkovice), but in terms of its historical significance it ranked just behind Brno. In 1910, approximately $36 \%$ of the population with the Czech language of daily use had been counted. The two towns thus displayed similar characteristics: they were centres with the existence of important administrative, cultural and educational institutions, and they had long been controlled by a German self-government whose representatives had tried to build the image of a German town, despite the fact that quite a large Czech minority lived there. ${ }^{7}$

Moravská Ostrava/Mährisch Ostrau was originally a small border town whose character changed very quickly with the rapid industrialization in the second half of the nineteenth century. The Ostrava-Karviná coal district quickly developed into one of the most important industrial centres of the Bohemian Lands and Moravská Ostrava became the destination of many immigrants, especially from Galicia, Moravia, Bohemia and even Germany. During the second half of the nineteenth century, a remarkable multiethnic society consisting of Czechs, Germans, Poles and Jews began to develop there. It was not until the turn of the twentieth century that major cultural and administrative institutions were established there and the town began its transformation into the cultural and administrative centre of the wider region.

Jihlava/Iglau, like Brno and Olomouc, is a statutory town. Located in the immediate vicinity of the historical Czech-Moravian land border, it became an important centre of silver mining in the Middle Ages, and in the eighteenth century it came to be a centre of cloth production, which began to economically stagnate during the nineteenth century. Jihlava became the centre of the so-called Jihlava language island (Iglauer Sprachinsel), which was one of the most important German-language enclaves in the Bohemian Lands. In 1910, nearly 49,000 inhabitants lived in 56 municipalities in the vicinity of Jihlava, both on Czech and Moravian territory, of which $79 \%$ claimed the German language of daily use. ${ }^{8}$

The last surveyed location will be, unlike the previously followed large towns, the small strategic North Moravian town of Zábřeh/Hohenstadt. As late as the midnineteenth century, it had only around two thousand inhabitants. The economic expansion connected with the development of the textile industry caused a gradual increase in population. From the national point of view, the town was located on the language border and was considered strategic by national activists. The share of the

7 KLADIWA - POKLUDOVÁ - KAFKOVÁ, Lesk a bída obecních samospráv, 36-37.

8 For more details regarding the situation of the language islands in Moravia at the time of the creation of the Czechoslovak Republic, see: BOHÁČ, Národnostní mapa republiky Československé, 97-105. JAŠŠ - FŇUKAL, The German language islands, 40-49. 
Czech-speaking population in the town was not insignificant (about $36 \%$ in 1880 , about $31 \%$ in 1910), and there was also a large area of Czech-language municipalities in the vicinity. National activation took place relatively belatedly in the area of the Zábreh political district, with a significant upswing occurring only at the turn of the 1880 s and 1890s, turning into a fierce struggle of national activists before the First World War. ${ }^{9}$

Table 1: The development of the ethnic situation of the surveyed towns in 1880,1910, 1921 and $1930^{10}$

\begin{tabular}{|l|c|c|c|c|c|c|c|c|c|c|c|c|}
\hline \multirow{2}{*}{ Town } & \multicolumn{4}{|c|}{ total population } & \multicolumn{3}{c|}{$\begin{array}{c}\text { \% claiming the German } \\
\text { language of daily use } \\
\text { (from 1921 nationality) }\end{array}$} & $\begin{array}{c}\text { \% claiming the Czech } \\
\text { language of daily use } \\
\text { (from 1921 nationality) }\end{array}$ \\
\cline { 2 - 14 } & 1880 & 1910 & 1921 & 1930 & 1880 & 1910 & 1921 & 1930 & 1880 & 1910 & 1921 & 1930 \\
\hline Brno/Brünn & 82,660 & 125,737 & 221,758 & 264,925 & 58.8 & 64.9 & 25.2 & 19.7 & 38.9 & 33.4 & 70.3 & 75.6 \\
\hline Olomouc/Olmütz & 20,176 & 22,245 & 57,206 & 66,440 & 63.8 & 59.6 & 27.7 & 22.6 & 30.4 & 36.1 & 68.5 & 72.0 \\
\hline M. Ostrava/M. Ostrau & 13,448 & 36,754 & 41,765 & 125,304 & 27.4 & 47.1 & 23.7 & 17.4 & 61.2 & 36.3 & 58.7 & 73.7 \\
\hline Jihlava/Iglau & 22,378 & 25,914 & 25,634 & 31,028 & 83.8 & 79.2 & 50.2 & 39.0 & 45.4 & 20.1 & 45.2 & 57.9 \\
\hline Zábřeh/Hohenstadt & 2,613 & 3,566 & 5,389 & 6,247 & 64.2 & 67.4 & 30.6 & 30.5 & 35.5 & 31.0 & 67.5 & 67.7 \\
\hline
\end{tabular}

\section{Moravian municipalities until 1918}

As soon as the revolution of the 1840 s removed servitude and the traditional supremacy of the manorial lords, it opened up the possibility of creating self-governing organizations that arose from the idea of natural rights. Perhaps the biggest gain was the introduction of municipal authorities on the basis of the provisional municipal system of March 1849. Since then, municipalities or, more precisely, their elected representatives had wielded considerable authority. ${ }^{11}$ The municipal authorities, based on the principle of electability and the representation of the interests of the individual population groups, became one of the basic segments of the civil society that was being built in the following decades. Municipal politics had thus become a "school" for politics practised at the level of both the Land Diet and the Imperial Council in Vienna, while at the same time providing an opportunity to promote the principles of democratic behaviour. ${ }^{12}$ On the other hand, the selection of the representatives of the municipal authorities was guided by the principle of census (i.e. tax charges) and constituencies (curiae), which gave the municipal politics an honorary character. This fact became increasingly at variance with the real social and national development and caused considerable social tension. ${ }^{13}$ This was compounded even more by the political failures of the Czech representatives at the Imperial Council in Vienna, whose attention

9 For more details, see: POPELKA, Proces české národní aktivizace, 103-136. POPELKA, Podnikatel jako národní agitátor, 41-67.

10 Sources: Statistický lexicon obcí v Republice československé. Vol. Il. Morava a Slezsko. Statistický lexicon obcí v zemi Moravskoslezské. KLADIWA - POKLUDOVÁ - KAFKOVÁ, Lesk a bída obecních samospráv.

11 For the genesis of the self-governing principle in the Bohemian Lands, see: HLAVAČKA, Zlatý věk české samosprávy. KLADIWA, Leska bída obecních samospráv.

12 MALÍR̆, Samospráva jako prostredek poslanecké kariéry, 152-164.

13 MALÍR̆, Nacionalizace obecní samosprávy, 73-93. 
was logically transferred to the area of self-government, whether at the provincial, district or, in particular, municipal level. ${ }^{14}$

The gradual nationalization of everyday life in the Bohemian Lands also began to be reflected in the functioning of the municipal authorities, making it, especially in ethnically mixed areas, increasingly difficult for the individual national groups to find consensus. In the Bohemian Lands, this fact was particularly striking in the milieu of Moravian towns, as in Moravia the language boundary was not as sharp as in Bohemia. Numerous minorities lived in most Moravian towns, towns with a German majority were often surrounded by Czech-language backgrounds and there were numerous socalled language islands. In 1890, of the 307 Moravian towns, only 50 had exclusively Czech and 36 exclusively German populations. The remaining towns and small towns were nationally mixed. ${ }^{15}$ In these nationally mixed Moravian towns, representatives of the Czech population were more and more insistent in claiming their share of power in the municipalities. This was the result of the demographic increase and social and economic emancipation of the Czech population in Moravia, but also of the spreading and strengthening of the Czech national idea in Moravia. ${ }^{16}$ This effort, however, ran counter to the interests of the economically more efficient German bourgeoisie, which used all legal means to maintain its power over the running of the municipalities. In Moravia, this clash resulted in the so-called battle for the town halls, during which both sides in the dispute clashed fiercely in the municipal elections with the aim of controlling the town hall. ${ }^{17}$

In many cases, the Czech representatives succeeded, but in most Moravian towns, including the largest, the Czech ambitions remained unfulfilled until the collapse of Austria-Hungary. As of 1910, of the thirty most populous Moravian municipalities, exactly half of the town halls were controlled by Czechs, but the German ethnic group retained control in the largest ones (Brno, Moravská Ostrava, Olomouc, Vítkovice, Jihlava, Znojmo). By contrast, by 1910 the Czechs had taken over the major towns in Haná (Prostějov, Přerov and Kroměříž), the populous Brno outskirts (Židenice, Královo Pole, Husovice), some growing municipalities in the Ostrava agglomeration (Mariánské Hory, Zábřeh nad Odrou) and some traditional regional centres (Uherské Hradiště, Třebíč). Of the six statutory towns in Moravia, four were controlled by Germans before the First World War, and only two by Czechs. ${ }^{18}$

\section{The situation in Moravian towns after the Great War}

After the Great War, the question of the municipal authorities came to a whole new level. The formation of Czechoslovakia brought not only a radical change in the political regime, but also a new phase in the development of relations within a nationally divided society. After the collapse of Austria-Hungary, the situation changed in that

\footnotetext{
14 VELEK, Rozvijení české samosprávy, 146-151.

15 BOHÁČ, Vývoj Čechův a Němcův na Moravě, 270-306, 366-389. RUMPLER- URBANITSCH, Die Habsburgermonarchie 1848-1918, 2267-2271. HLAVAČKA, Der Zerfall des Reiches, 94.

16 MALÍř - ŘEPA, Morava na cestě k občanské společnosti, 176-185. ŘEPA, Moravané nebo Češi, 169-208.

17 Concerning the so-called battle for the town halls, see: MALÍř, Obecní samospráva a národnostní problematika, 75-87. MAREK, Prostějov v moravské politice, 14-19. VIKTOŘíK, Z „bojů o radnice" moravských měst, 81-108.
}

18 KLADIWA - POKLUDOVÁ - KAFKOVÁ, Lesk a bída obecních samospráv, 36-37. 
the new state power, unlike its predecessor, directly identified with one nationality (the concept of the nation state of Czechs and Slovaks or, more precisely, Czechoslovaks). ${ }^{19}$

From the aspect of the existence and functioning of the municipal authorities just after the coup d'état in October 1918, an important role was played by provisional revolutionary bodies - national committees. The network of national committees was created as an alternative power network that was to quickly dominate and take over the functions of the existing power structure, consisting of both state authority and municipal authority bodies. The Central Czechoslovak National Committee in Prague maintained contacts with both the Provincial National Committee in Brno and the network of more than 200 district national committees and 76 local national committees, gradually taking power in the individual regions. According to the nominations of the Czech political parties, the national committees were composed primarily of Czech national activists - Czech secondary school teachers, lawyers, sole traders or members of the Sokol sports organization. ${ }^{20}$

In areas with a more prominent Czech majority, the taking of power through the national committees basically took place without any major problems, immediately at the turn of October and November 1918. However, the situation was more complicated in ethnically mixed areas or areas inhabited exclusively by a German population. In areas with a German majority, those competing for power included, on the one hand, the minority Czech national committees and, on the other, German municipal councils and politicians, who invariably linked their future to the emerging Deutschösterreich. ${ }^{21}$ By Act No. 40 of 22 November 1918, the Deutschösterreich Parliament declared the German provinces situated in the Bohemian Lands to be its territorial possession. ${ }^{22}$ However, given the foreign political situation, this was only a formal declaration. From the end of November 1918, Czech conscripts began occupying the territories with a German majority, which lasted until early 1919. With some exceptions, there was no major resistance during the occupation of the territory, and the paralysed German population had to accept the fact of having to remain within the forming Czechoslovakia. The strong initiative of the State Council in Vienna, which sought to internationalize the problem and called for a plebiscite, did not help either. In September 1919, the Treaty of Saint-Germain-en-Laye brought a definitive end to the idea of the regions with a German majority in the Bohemian Lands joining Deutschösterreich. ${ }^{23}$

It is true that, from the point of view of the development of self-government, the existing norms of the Austrian legal order were also taken over in connection with the adoption of the so-called Reception Law for reasons of legal continuity, but from the beginning it was clear that the existing principles of municipal elections would change, especially considering that they had remained essentially the same since the 1860s. As early as 6 November 1918, after consulting experts, the Prague National Committee decided to amend both the municipal constitution and the election rules as soon as possible. In January 1919, new election rules were issued

19 HUDEK - KOPEČEK - MERVART, Čecho/slovakismus, 149-201. KLADIWA et al. Národnostnístatistika v českých zemích, 33-38.

20 For more detail concerning national committees, see: PEŠA, Národní výbory v českých zemích, 45-46. PEŠA, Národní výbory $v$ roce 1918, 249-289.

21 KESSLER, Češi a Němci v roce jedna, 143-164. MOLISCH, Die sudetendeutsche Freiheitsbewegung.

22 KOCHNE, Die unbeabsichtigte Republik, 74-78. 
concerning municipalities, introducing universal, direct and equal suffrage (or, more precisely, election duty). ${ }^{24}$ Then, in February of the same year, an amendment to the municipal constitution was issued, which brought one crucial point in terms of the subject under consideration. In Section 23, the government was given the option of merging or dividing municipalities and changing municipal and district boundaries by the end of 1919. To do so, the government did not need the consent of either the municipalities concerned or authorities of any type, with the municipalities or, more precisely, their inhabitants only having the opportunity to comment on the given plan. This authorization was later extended by subsequent legislation until 1924, with the condition that it concerned proceedings initiated before the end of 1920 . Due to its large workload, the government authorized the Ministry of the Interior to directly deal with this agenda by a resolution of 30 July $1919 .{ }^{25}$

The possibility of merging or dividing municipalities without any restriction, acquired by the government in early 1919, was not formal and caused a number of controversies from the very start, mainly due to the fact that the political authorities had been given substantial authority until then belonging to self-governments. Since Section 23 appeared to be exceptional at the time of its issuing, it was to be expected that the government would apply it especially in cases where a change in the municipal land register was desirable in the interest of the whole state and where the impulse came from an official initiative, not from the municipal authorities themselves. It is true that a large part of the cases of municipality mergers in the early days of the Czechoslovak Republic bore signs of an effort to solve the national problems that had been accumulating in the local communities for years. The questions of the rationalization of the administration of the merged municipalities had more of a "secondary" effect, which could be used to justify the merging of the municipalities. We can say that in the milieu of Moravian towns it was a continuation of the socalled battle for the town halls, though conducted in a new era by new means. The fundamental difference compared to in the Austro-Hungarian era, when the question of the composition of the municipal councils was entirely in the hands of the local society, was that now the interest of the central institutions of the new state and the various interest groups (especially national unions) was reflected quite clearly in municipal affairs.

After the First World War, the issue of merging became, in effect, topical for all types of municipalities, from the largest Czech and Moravian towns (Brno, Olomouc, Moravská Ostrava, Jihlava, Znojmo, Liberec, České Budějovice, Plzeň) to small rural towns. What was essential were the changes that occurred in the administrative organization for municipalities located at a language border or on the territory of language islands, as here the pressure to quickly resolve the national situation in favour of the Czech minority was particularly acute.

24 Sbírka zákonů a nařizení státu československého, 1919,77-88. For comparison, see: BADER-ZAAR, Demokratisierung des Wahlrechts, 101-112.

25 Sbírka zákonů a nařizení státu československého, 1919, 89-91. 
The key Moravian residential agglomerations: Brno, Olomouc, Ostrava

The model for the post-war merger actions was the creation of the so-called Velké Brno and Velká Olomouc, which were enacted on 16 April 1919. The outcome of the legislative process was analogous, very concise laws, the provisions of which make it quite clear that they were drafted in the context of the upcoming municipal elections (Sections 2-4 of both laws specifying the number of municipal representatives and the conditions for municipal elections). ${ }^{26}$ In both cases, the predominantly Czech outskirts were merged with the town centres with a German majority - in the case of Olomouc, 13 previously separate municipalities were merged, and in the case of Brno, as many as 23 municipalities. This created the precondition for a legal takeover of the town halls of key statutory towns by Czech representatives as part of the upcoming municipal elections.

That this merger was motivated primarily by political and national reasons was not much concealed by its authors. In the case of Olomouc, Administrative Commissioner Richard Fischer wrote the following in a letter dated $15^{\text {th }}$ January 1919 and addressed to the National Assembly:

The coup d'état has brought the self-governments in many municipalities in Moravia and Bohemia into Czech hands, even in areas where, according to the latest census, there is no Czech majority. Perhaps the change in the political situation will result in an increase in the Czech population; it is very doubtful whether we will achieve a majority in the municipal elections with the new municipal rules. For this reason, we intend to merge 13 suburban municipalities with Olomouc.... We are already working on this project, but it is not certain that it will take place before the elections. If the German majority, though not very large, were to come to govern in Olomouc, it would mean a great detriment to our development, both moral and national-political. The same considerations will probably be determinant for Brno, Zábřeh, Mor. Ostrava, Jihlava, Liberec, etc. That is why, in our opinion, it would be advisable to postpone the elections in those towns where the merging of the neighbouring municipalities is an issue until, for example, the end of this year. In the meantime, our numbers will increase due to Czech clerks, sole traders and workers returning from military service, from captivity, etc., and then our majority can finally be achieved. ${ }^{27}$

Both in the Brno residential agglomeration and in the Olomouc region, the merging process continued very quickly, though in both cases it was not without protests from the German representatives. In late October 1918, a rapid power transition took place both in Brno and in Olomouc, where the local national committees took over all major legal institutions in a matter of days. In both cases the only exceptions were the military garrisons and town councils. ${ }^{28}$ However, the Brno Town Council remained in its original composition until 5 November 1918. It was only after mass street protests connected to the pressure from the Provincial National Committee that the Brno representatives

26 For Brno: Sbírka zákonů a nařizení státu československého, 1919 (16 April 1919). For Olomouc: Sbírka zákonů a nařizení státu československého, 1919 (16 April 1919).

27 Státní okresní archiv Jihlava (hereinafter SOkA Jihlava), Městská správa Jihlava, presidial registry, cart. no. 9, inv. no. 1132.

28 BARTOŠ - TRAPL, Dějiny Moravy 4, 7-12. 
were forced to step down, and on 6 November the former Přerov District Governor, Petr Kerndlmayer, took control of the town in the function of Administrative Commissioner. ${ }^{29}$ Two days later, a 24-member administrative committee was appointed with a twothirds Czech majority.

Even shortly after the coup, the town hall in Olomouc was also being run by the government elected in the elections of 1910 and the supplementary elections of 1912. On 29 October, the Mayor of Olomouc received representatives of the National Committee, headed by Richard Fischer, but agreed with them only on the need to maintain peace in the town and provide supplies to the severely suffering population. ${ }^{30}$ After his consultation with the Provincial National Committee in Brno, on 7 November Richard Fischer, on behalf of the National Committee, called on the town council to resign. The town council resigned on 11 November only after an ultimatum from the National Committee. However, it noted that it was involuntarily bowing to pressure and that the proposed composition of the Administrative Committee, where the Czechs were to have double superiority, was unacceptable to the German population. ${ }^{31}$ The Administrative Committee did not hold its first meeting until 17 November, for a surprising reason: the $C$ zech public officials were unable to agree on the composition of the Czech members of the Administrative Committee. In addition, the German representatives protested against the person of the Government Commissioner at the Moravian Viceregency, which, however, rejected their complaint on 16 November, confirming Richard Fischer as the Government Commissioner. ${ }^{32}$

Lively discussions about the merging of municipalities in the Brno agglomeration had already begun in late October 1918. On 29 October, representatives of the municipal councils of Czech municipalities grouped up in the Association of the Brno Suburbs (Spolek brněnských předměstí) declared their will to join the centre of the agglomeration and to create "one great Czech Brno".33 The first major meetings on this matter took place on 14 and 27 December 1918, when the provisional government of the town first met with the representatives of ten municipalities of the agglomeration and two towns (Husovice and Královo Pole), and then with the representatives of sixteen suburban municipalities. At the meetings, the scope of the merger was discussed, i.e., which municipalities should be merged with Brno. It was clear from the meetings that, in the vast majority, the Czech representatives supported the merger, which was also confirmed in early 1919 by the official statements of the municipalities of the Brno residential agglomeration, where 18 of them expressed their support for the merger. However, they usually conditioned their consent on the completion of the municipal infrastructure, which was also a common requirement for the municipalities in the Olomouc or Ostrava regions. ${ }^{34}$ Major problems occurred in only two municipalities with a German majority (Přízřenice and Dolní Heršpice), but they were included on the

29 We can observe a similar scenario of forced resignations of town councils in a number of other nationally mixed towns whose town halls were controlled by German representatives. See: KING, Budweisers into Czechs and Germans, 154-158.

30 Státní okresní archiv Olomouc (hereinafter SOkA Olomouc), Archiv města Olomouce, presidial registry, cart. no. 30 , inv. no. 566 .

31 Letzte Sitzung des Stadtverordneten-Kollegiums. In: Mährisches Tagblatt, 1918 (12 November), p. 4.

32 SOkA Olomouc, Archiv města Olomouce, presidial registry, cart. no. 30, inv. no. 584.

33 FASORA - ŠTĚPÁNEK, Dějiny Brna 6, 31-32.

34 FASORA - ŠTĚPÁNEK, Dějiny Brna 6, 34-35. 
list of merged municipalities despite the protests of their municipal councils. At the beginning of February, the Administrative Committee supported the plan to merge the municipalities of the Brno agglomeration, but only because of the predominance of Czech representatives - all eight German members of the committee opposed it. The merging of the municipalities of the Brno agglomeration was enacted very quickly, also due to the draft of the relevant law having already been prepared by the Brno Advisory Council in January 1919. ${ }^{35}$ In addition, the Ministry of the Interior itself, in its letter of 22 January 1919, asked the Brno Administrative Committee not to delay the preparations for the expansion of the city. The practical result was that as early as April 1919, the second-largest town in Czechoslovakia was formed by means of an administrative merger, with a population of almost 222,000 in $1921,70.3 \%$ of which claimed Czechoslovak nationality, 25.2\% German nationality and $1.3 \%$ Jewish nationality. ${ }^{36}$

This new state of affairs was directly reflected in the results of the first post-war municipal elections. These took place after a tense election agitation on 15 June 1919. In total, there were 120,107 eligible voters in Velké Brno, of whom 86,294 (71.8\%) were Czech and 33,813 (28.2\%) German. $86.4 \%$ of eligible voters participated in the elections, who, after a small number of invalid votes was subtracted, cast $65.9 \%$ of votes for Czech political parties, $31.7 \%$ for German political parties and $2.4 \%$ for Jewish parties. In Brno itself, i.e. within the boundaries Brno had before 16 April 1919, the number of German and Czech votes was much more equal: 33,742 for Czech parties and 28,881 for German ones. This is a good illustration of how disadvantageous the formation of Velké Brno was for the Germans. The election results show that despite the huge $\mathrm{Czech}$ agitation, the German voters were relatively more conscientious. The large turnout of the German voters was undoubtedly due to the successful agitation by the German Social Democrats, and it appears that the German parties were much more united in the elections. Thus, the German political parties did not fare badly at all in Brno against the Czech numerical superiority, and the German Social Democrats in particular achieved extraordinary success, becoming the third strongest party. On the other hand, the Czech political parties manifested a much greater inter-party struggle. The Czech press reacted to the large number of German votes with its rhetoric, urging people to unite for the Czech cause, as there was still a lot of work to be done to make Brno nationally what it should be, i.e. Czech. ${ }^{37}$

In the 90-member municipal government, the Czech parties had thus gained a relatively comfortable two-thirds majority. After the elections not only the election of the mayor took place, but also several meetings of the municipal government and the town council. However, not only the German parties, but also the closely second National Democrats were grossly dissatisfied with the results. On the basis of three complaints, which pointed out, among other things, the large number of outstanding election complaints, the election results were annulled by the provincial political administration in October 1919. ${ }^{38}$ By the new elections, held on 29 February 1920, power had passed back to the Administrative Commissioner and to the extended Administrative Committee. However, the February elections, accompanied by

35 VRÁNA - SCHELLE, Vznik velkého Brna, 21-30. MATES - SCHELLE, Ke vzniku Velkého Brna, 107.

36 Statistický lexicon obcí v Republice československé. Vol. II. Morava a Slezsko, 28.

37 BURIAN, Brněnští Němci a teritoriálně-politické proměny, 83-85.

38 MATES, Obecní volby $v$ roce 1919, 22-23. 
nationalistically fierce rhetoric, essentially only confirmed the previous results. Of the total 115,989 votes cast, 78,149 votes (67.4\%) went to ten Czech political parties, 35,298 votes $(30.4 \%)$ to three German parties, and 2,542 votes ( $2.2 \%$ ) to the associated Jewish parties. From the Czech parties the victorious Social Democracy strengthened its position even further, eventually winning its former mayoral post. ${ }^{39}$

The takeover of the Olomouc Town Hall by the Administrative Committee with a Czech majority was perceived by the Czech side as "gaining the town", though, like in Brno, the acquired status had to be confirmed in the municipal elections. ${ }^{40}$ The Olomouc Administrative Commissioner envisaged the same solution as in Brno, Moravská Ostrava and other important towns, namely the merging of the town with suitably chosen suburban municipalities. Before 1914, the Olomouc burghers, keeping to the motto "klein aber mein", blocked all proposals to merge the suburban municipalities. ${ }^{41} \mathrm{It}$ was not until 1916 that consideration was given to merge the predominantly German Neředín. However, after the coup d'état and major changes at the Olomouc Town Hall, the situation quickly turned. As early as 9 December 1918, the Administrative Commissioner submitted a proposal for the creation of Velká Olomouc. Archive material shows that he had consulted and coordinated his steps with representatives of the administrative committees in both Prague and Brno. At that time Fischer proposed to negotiate first with the predominantly Czech Hodolans (who agreed to merge with Olomouc at the meeting of the municipal government on 19 December), while the German members of the Administrative Committee preferred the mainly German Nová Ulice. ${ }^{42}$

Negotiations with the surrounding municipalities were ultimately very quick. As early as 27 December, a meeting of all the municipalities concerned took place, at which all thirteen representatives of the contacted municipalities agreed to the proposal for the creation of Velká Olomouc. Six of these municipalities were predominantly German (all governed by administrative committees in which Czech representatives held a twothirds majority), the remaining seven were Czech. ${ }^{43}$ Other documents show that one of the main arguments for the merger was "to break through from the Czech side during the municipal elections and into the Chamber of Commerce". ${ }^{44}$ In reality, however, at least some of the municipalities had hesitated for a long time over the official decision to merge. A report from the Ministry of the Interior dated early April 1919 stated that the municipalities of Černovír and Lazce had not yet made the necessary resolution to agree to the merger and that the municipality of Berlidla had requested the communication of detailed conditions. ${ }^{45}$ In the final stage, however, there was no disagreement with the merger plan on the part of the municipalities concerned. The result was therefore Velká Olomouc, with a population, according to the results of the 1921 census, of

39 VYKOUPIL, Brno mezi dvěma válkami, 26-27. Občanské noviny, 1920 (6 January). Občanské noviny, 1920 (27 February). Lidové noviny, 1920 (13 February; 28 February).

40 Concerning the municipal elections in Olomouc before 1918, see: FISCHER, Česká účast při obecních volbách.

41 HÁJEK, Olomoučtí Němci 1918-1938, 41.

42 SOkA Olomouc, Archiv města Olomouce, register 1920-1940, cart. no. 15. SOkA Olomouc, Archiv města Olomouce, books, inv. no. 455, sign. 2098. HÁJEK, Olomoučtí Němci 1918-1938, 40-41.

43 SOkA Olomouc, Archiv města Olomouce, register 1920-1940, cart. no. 15.

44 SOkA Olomouc, Archiv města Olomouce, register 1920-1940, cart. no. 15.

45 SOkA Olomouc, Archiv města Olomouce, register 1920-1940, cart. no. 15. 
57,206 inhabitants, of which $68.5 \%$ claimed Czechoslovak nationality, $27.7 \%$ German nationality and $1.4 \%$ Jewish nationality. ${ }^{46}$

The municipal elections were held in Olomouc, as in Brno, on 15 June 1919, which the Czech politicians in Olomouc considered too rushed, but they failed in their request to the government to postpone the elections until the end of the year. In the election campaign, the German politicians publicly denounced the Czech "manoeuvre" with Velká Olomouc and could only foresee the election of a Czech majority to the town hall. ${ }^{47}$ The results of the municipal elections confirmed this logical assumption. In the 60 -member municipal council, the Czech parties gained 38 mandates $(64.8 \%$ of the votes), German parties 20 mandates (34.9\% of the votes) and the united Jewish parties two mandates (3.0\%). In the overall context the German result can be assessed as very good. ${ }^{48}$

However, in the case of the merged municipalities in the Olomouc region we can subsequently observe centrifugal trends, as some municipalities merged with Olomouc felt cheated. As early as 1920-1921, under the impression of the dire financial condition of the Town of Olomouc, severe centralization and poor functioning of the new municipal authority, Chvalkovice, Povel and Nové Sady, i.e. municipalities both Czech and German, demanded back their independence. For example, according to the Chvalkovice representatives, who had approached the Ministry of the Interior on the matter, the whole merger action had been carried out for profit reasons and "due to the merger, this Czech suburb [was] being drained financially by the large German capital" and none of its needs were being taken into account. The allegedly perfectly functioning local town hall was closed down (in the merged municipalities, office work ceased on 30 June) and instead the local residents were subjected to the supposedly terrible official machinery of the central town hall. Complete discontent was supported by all local associations and parties. In all cases, both the provincial political authority in Brno and subsequently the Ministry of the Interior opposed the demands for renewed independence. ${ }^{49}$ In early 1921, other municipalities officially demanded economic autonomy along the lines of the Brno municipalities and a higher share in the administration. In order to ensure the rational functioning of the town administration, they submitted a plan, based on Richard Fischer's proposal from April 1920, for the creation of special provisional advisory councils in the merged municipalities, counting 12-24 members, to manage the economic affairs of the given town district. This somewhat eased the tensions between the central town hall and the individual parts of the town. ${ }^{50}$

On the other hand, the example of the Ostrava residential agglomeration shows that in some cases the negotiations concerning the merging of municipalities were significantly more complicated. Like in Brno and Olomouc, the actual takeover by the National Committee took place relatively smoothly in Moravská Ostrava. The 12-member District National Committee in Moravská Ostrava, headed by Social Democrat Jan Prokeš, took over the state institutions on 29 October 1918. On the same day, the Moravian-Silesian Municipal Committee took note of the proclamation

46 Statistický lexicon obcí v Republice československé. Vol. II. Morava a Slezsko, 63.

47 Mährisches Tagblatt, 1919 (2 June; 13 June).

48 Deset let práce na olomoucké radnici 1918-1928, 20.

49 SOkA Olomouc, Archiv města Olomouce, register 1920-1940, cart. no. 16.

50 SOkA Olomouc, Archiv města Olomouce, register 1920-1940, cart. no. 15. 
of the new Czechoslovakia and, with regard to maintaining order and supplies, was willing to establish contacts with the representatives of the National Committee. ${ }^{51}$

Like in other towns, in the Ostrava region, too, the National Committee was involved in the process of removing the existing municipal councils. In particular, on 19 November, the National Committee sent a letter to the Ministry of the Interior, initiating the removal of the municipal committees of Moravská Ostrava, Prívoz and Vítkovice, i.e. the three most important municipalities with town status in the Ostrava region. At that time, the National Committee informed the government of the popular discontent regarding the fact that these towns continued to be governed by bodies elected on the basis of the old election rules. ${ }^{52}$ The first proposal envisaged the creation of administrative committees counting 24 members, with 18 seats for the representatives of Czech political parties and the remainder for German political representation. In early December, the government agreed to make changes to the management of these towns, which was followed by negotiations between the National Committee and the relevant municipal committees. The result was the forced resignation of the members of the municipal committees in Moravská Ostrava, Vítkovice and Prívoz on 17 December and the appointment of administrative commissioners, which was, in all cases, accompanied by protests over the low proportion of German representatives in the administrative committees. ${ }^{53}$ The most influential Administrative Commissioner in the Ostrava region was the Moravská Ostrava Social Democratic politician, Jan Prokeš, who ultimately had a 29-member Administrative Committee at his disposal, nominated, like in other cases, on the basis of a political quota ( 7 German and 22 Czech representatives). ${ }^{54}$ In Prívoz and Vítkovice, 24-member administrative committees (in Vítkovice 14 Czechs and 10 Germans, in Přívoz only 6 Germans and 18 Czechs) were formed. Despite being, by their very nature, provisional bodies, in the case of Moravská Ostrava their operation was extended to a lengthy six and a half years. The main reason for this was the negotiation regarding the so-called Velká Ostrava, a project that was to follow the example of the projects of Velké Brno and Velká Olomouc.

Although there had already been some indications of first reflections on the merging of municipalities in the Ostrava region before 1914, the idea of merging fifteen Moravian and Silesian municipalities in the residential agglomeration was purely post-war. According to the local census of 1919, the planned Velká Ostrava would, with its 166,000 inhabitants, become the third largest town in Czechoslovakia, and since more than $64 \%$ of these inhabitants were Czechs, the merging of the municipalities would result in the neutralization of the key town halls in Moravská Ostrava, Vítkovice and Prívoz, which had, before the arrival of the administrative commissioners, been controlled by a German majority. ${ }^{55}$

The Administrative Committee of Moravská Ostrava, headed by Jan Prokeš, opened preliminary negotiations with 14 municipalities in the Ostrava residential agglomeration

51 JIŘík, Státní převrat na Ostravsku v roce 1918, 402-427. Obecní výbor Moravské Ostravy v novém státě. In: Moravsko-slezský deník, 1918 (31 October), no. 301, p. 2.

52 Archiv města Ostrava (hereinafter AMO), Okresní národní výbor Moravská Ostrava, cart. no. 1 and 2.

53 AMO, Okresní úřad Moravská Ostrava (hereinafter OÚMO), cart. no. 16. AMO, Okresní národní výbor Moravská Ostrava, cart. no. 2.

54 AMO, Archiv města Moravská Ostrava (hereinafter AMMO), books SK, 1918, II B 246. AMO, OÚMO, sign. LC $363 / 1919$.

55 PRZYBYLOVÁ, Ostrava, 336-337. 
in March and April 1919 and, according to its statement, the representatives' reactions were essentially positive. On 5 May 1919, the Committee therefore decided to ask the government to create Velká Ostrava and consequently to postpone the date of the municipal elections, to which the Ministry of the Interior consented. However, the situation in some municipalities was not so simple. As late as May 1919, the administrative committees of Vítkovice and Svinov expressed a clearly negative opinion on the merger plan. In contrast to the surrounding municipalities, the key municipality of Vítkovice had an excellent municipal infrastructure, was minimally indebted and was worried about a sharp increase in the municipal surcharge. ${ }^{56}$ The Svinov Administrative Committee had different arguments against the merger, as it was concerned about the willingness to implement the costly infrastructure projects needed by the municipality after the merger and about the transfer of all industrial plants harmful to health from the centre to the peripheral municipalities of the new town. ${ }^{57}$ Interestingly, by June 1919, Jan Prokeš had managed, after a number of concessions, to get approval for the merger even from those administrative committees that had still been protesting against it in May. On 24 September 1919, after obtaining the consent of all administrative committees, the Administrative Committee of Moravská Ostrava sent a proposal to the Czechoslovak government for a law to merge seven Moravian and eight Silesian municipalities into the "Mining Town of Ostrava". ${ }^{58}$

However, as in other cases, spontaneous "bottom-up" activity worked alongside the key initiative from above. Thus, in May 1919, Silesian Vratimov spontaneously expressed support for the idea of creating Velká Ostrava, claiming that it had close ties to the neighbouring Silesian municipalities that were expected to merge with the new town. A similar request was made in December 1920 by the representatives of the municipality of Nová Bělá and Proskovice, who (along with many other municipalities of the District of Moravská Ostrava) protested against the intention of incorporating their municipality into the Místek District. ${ }^{59}$

However, there were as many as four problems that complicated the merger plan: 1. The unresolved state affiliation of the Cieszyn region, to which all the Silesian municipalities concerned belonged, except for Svinov; 2 . The question of which land the emerging town would belong to. The Regional Administrative Committee for Silesia contested the decision to make the former Silesian municipalities a part of Moravia. The reasons were both financial and national, as a change in the land affiliation of the Silesian municipalities could have led to a weakening of the Czech positions in the Cieszyn region, which many representatives saw as incomprehensible in the context of the international dispute over this area. 3. Legislation which, until 1920, did not address the issue of changes to the municipal borders, which would have resulted in changes to the borders of the historical lands. 4. The fact that some municipalities, especially Vítkovice, had, for a long time, acted tactically, issuing various conflicting proclamations on the issue of merging with Moravská Ostrava. ${ }^{60}$

56 AMO, AMMO - new registry, 1919-1923, inv. no. 47, cart. no. 10.

57 AMO, Okresní úřad Moravská Ostrava, cart. no. 53, sign. Lb 9, inv. no. 417.

58 AMO, AMMO - new registry, 1919-1923, cart. no. 10 a.

59 AMO, Okresní úřad Moravská Ostrava, cart. no. 53, sign. Lb 9, inv. no. 417.

60 For example, in December 1920 the Vítkovice Administrative Committee did not withdraw its initial agreement to merge with Moravská Ostrava, but at the same time approved a proposal to establish the so-called Velké Vítkovice, which was to be created by the merger of this industrial centre with the neighbouring Zábřeh 
Act No. 285 of 14 April 1920 unblocked the problem of changes to the land and county borders. The question of Velká Ostrava's land affiliation eventually became crucial, as neither land wanted to lose a significant source of land surcharges and, as the Ministry of Finance admitted in the middle of the negotiations in November 1920, "the negotiations are likely to be very difficult". In the original proposal of the Moravská Ostrava Administrative Committee, dated September 1919, it was envisaged that the new town should be incorporated into Moravia, which provoked expected opposition on the Silesian side. ${ }^{61}$ After another year of various protests, in October 1920 the government authorized the Ministry of the Interior to issue a decree on the merger of fifteen Ostrava municipalities and their incorporation into Silesia (issued on 13 November), which, however, did not solve the situation at all. Due to the intransigence of both lands on the question of the affiliation of Velká Ostrava, in February 1921 Jan Prokeš negotiated with Prime Minister Jan Černý, who saw the solution in promoting a new system of governance based on the abolition of the previous lands and the introduction of the county principle. ${ }^{62}$ In April 1921, Prokeš even proposed to the Ministry of the Interior that, in the event of an unsuccessful negotiation between the Moravian and Silesian provincial committees, it make the decision alone by the power of its authority. ${ }^{63}$ Due to further delays, Prokeš asked the Ministry of the Interior as well as the then prime minister Edvard Beneš if it would be possible to at least grant the request to form Velká Ostrava by merging the seven Moravian municipalities that were most interested in doing so. ${ }^{64}$ The government did not oppose this plan, but as early as February and subsequently in September 1922, the National Council for the Ostrava and Cieszyn regions, which represented the Czech political parties in Silesia, criticized this intention. In terms of the strategic reinforcement of the Czech element in Silesia, the council continued to insist on the original project of Velká Ostrava and on the integration of the new town into the administrative structures of Silesia. Similar protests also came from some Silesian municipalities (Slezská Ostrava) or corporations, mainly drawing attention to the risk of a fragile Czech majority.

Ultimately, both the Ostrava and Prague politicians negotiated primarily according to the sway of political arguments. An estimate of the political representation of the individual nationalities for the narrower option of the project indicated that the new 60-member municipal council would have a majority for Czech state-forming parties. On 10 October 1923, the Ministry of the Interior announced its intention to merge six municipalities (Přívoz, Vítkovice, Mariánské Hory, Zábřeh nad Odrou, Nová Ves and Hrabůvka) with Moravská Ostrava. ${ }^{65}$ In the administrative committees of the municipalities concerned, the project did not meet with stronger resistance and was approved by the majority, which was, however, not true of the public, which was divided

and Hrabůvka. The Administrative Committee then presented this proposal as the first stage towards Velká Ostrava, which was to be created sometime in the future. AMO, fund Okresní úrad Moravská Ostrava, cart. no. 53. sign. Lb 9, inv. no. 417. AMO, Archiv města Moravská Ostrava - new registry, cart. no. 10.

61 AMO, Okresní úrad Moravská Ostrava, cart. no. 53, inv. sign. Lb 9, inv. no. 417. AMO, AMMO - new registry, 1919-1923, inv. no. 47, cart. no. 10.

62 AMO, AMMO - new registry, 1919-1923, cart. no. 10 a.

63 AMO, AMMO - new registry, 1919-1923, cart. no. 10 a.

64 AMO, Okresní úřad Moravská Ostrava, cart. no. 53, sign. Lb 9, inv. no. 417. AMO, AMMO - new registry, 19191923, cart. no. 10 a.

65 AMO, AMMO - new registry, 1919-1923, inv. no. 47, cart. no. 10. 
on the matter. ${ }^{66}$ The merger was confirmed by the government of the Czechoslovak Republic on 20 December 1923 with effect from the beginning of 1924. Although the size of the new Moravská Ostrava was half the originally planned size, the population of almost 114,000 made it the third largest town in Czechoslovakia. The objections of a number of corporations that the merger put together municipalities of a different character, with no economic links among them, were rejected as unfounded. ${ }^{67}$

With the creation of a new town, the still functioning administrative committees disappeared, but until the regular municipal elections the new town continued to be run by Administrative Commissioner Prokeš together with a 42-member advisory council, whose composition was based on the results of the political parties in the previous general elections, in 1920 . The German representatives thus won only nine seats on the Administrative Committee, and the representatives of Jewish parties two seats. The remaining posts were filled by $C$ zech representatives; the Social Democrats held the strongest position -17 seats. The constituent meeting of the new Administrative Committee took place on 23 February $1924 .{ }^{68}$ However, it was disconcerting that more than five years after the removal of the duly elected selfgovernments, the administration of the Ostrava municipalities still remained in the hands of the administrative commissioners. As time went on, with the creation of the metropolis still nowhere in sight, opposition members grew increasingly averse to the Administrative Commissioner, and protests against his continued tenure multiplied. When the German members of the Administrative Committee discovered the futility of their protests, they moved on to passive resistance. There were even repeated accusations that Prokeš was delaying the negotiations to merge the municipalities in order to maintain his position and thus, regardless of the opinion of the German minority, to enforce actions detrimental to its interests and rights. ${ }^{69} \mathrm{It}$ is clear, however, that the merger itself was delayed primarily by external circumstances over which Jan Prokeš could have had only little influence.

As in other cases, the issue of the new municipal elections had become a very sensitive one. The municipal elections in Moravská Ostrava were held on Sunday, 9 November 1924. The Czech parties gained a total of 44 mandates (including seven communist ones), the German parties fourteen and the Jewish party two mandates. Due to complaints, the term of office of the Administrative Commissioner was extended until the spring of 1925 . It was only the constituent meeting of the new 60 -member municipal council, connected with the election of the mayor (Jan Prokeš, as expected) and two deputies (candidates of the National Socialists and the People's Party), that ended the long-term provisional measure on 17 March $1925 .^{70}$

66 Most of the criticism came from associations and political parties based in Vítkovice, who saw the merger with Moravská Ostrava as an economic disaster. AMO, AMMO - new registry, 1919-1923, inv. no. 47, cart. no. 10.

67 AMO, Okresní úřad Moravská Ostrava, cart. no. 53, sign. Lb 9, inv. no. 417. AMO, AMMO - new registry, 19191923, inv. no. 47, cart. no. 10.

68 AMO, AMMO - new registry, 1919-1923, cart. no. 10.

69 AMO, AMMO - new registry, 1919-1923, inv. no. 47, cart. no. 121.

70 AMO, AMMO - new registry, 1919-1923, cart. no. 114. 
The unwanted merging of municipalities? The case of the Statutory Town of Jihlava

The National Committee, as a provisional body of the Czech political representation, was formed in Jihlava on 30 October and was headed by the long-time leader of the Czech minority in Jihlava, advocate and former deputy of the Moravian Land Diet, JUDr. Ludvík Chlum. ${ }^{71}$ The very next day, the Jihlava National Committee managed to take control of the District Governor's Office, headed by Consensual Governor Karl Ludwig. Although the National Committee had thus gained control of the office governing the municipalities surrounding Jihlava, the town itself continued to be controlled by the existing town council as a body of political administration. From the beginning, however, the Jihlava Town Council refused to negotiate with the National Committee in any way, promoting Jihlava's incorporation into German Austria. In relation to the National Committee, it was only willing to make a compromise on the basic issues of supplies and security. Therefore, on 1 November, the Jihlava National Committee proposed to the National Committee in Prague to remove Jihlava's status as a statutory town and to transfer the political agenda to the District Governor's Office. ${ }^{72}$ However, as with most other Moravian statutory towns, this did not happen until ten years later and in a completely different situation. ${ }^{73}$

On 3 November 1918, a counterweight was established to the Jihlava National Committee - Deutscher Volksrat für die Iglauer Sprachinsel - formed from the representatives of the Jihlava Municipal Authority and the authorities of the German municipalities of the Jihlava language island, the German political parties and important associations. Deutscher Volksrat, headed by Jihlava entrepreneur and German activist Veno Sedlak, declared the will of the Germans of Jihlava as well as the entire language island to join Deutschösterreich, taking practical steps to achieve this goal. This organization covering Jihlava's Germans existed until August 1923, when its operation was officially suspended due to illegal activities. ${ }^{74}$

It was not until 3 December 1918 that the town council was forced to resign, handing over the administration to Administrative Commissioner František Hovưrka (the former Commissioner of the District Office in Jihlava) and a 24-member Administrative Committee with a parity representation of both nationalities and a decisive vote for the Administrative Commissioner. The resigning town council officially declared that it considered its resignation to be coerced, and though it had conformed to the laws and regulations of the Czechoslovak Republic, it proclaimed itself in favour of German Austria, leaving the final affiliation of the town to the decision of the peace conference. ${ }^{75}$ Thanks to the coup in the municipal authority, the Czech minority managed to gradually eliminate German dominance both in important offices and in education. ${ }^{76}$

However, the overall tense atmosphere was confirmed by the situation surrounding the municipal elections in 1919. In most municipalities of the Jihlava language island, they took place on the due date ( 16 June) and confirmed German dominance. In Jihlava and the nearest municipalities, however, their date was postponed by a decree from

71 PALÁNOVÁ, Poslanci Moravského zemského sněmu, 47-54. RANDÝSEK, Jihlavský národní výbor, 205-211.

72 SOkA Jihlava, Městská správa Jihlava od roku 1849, presidial registry, cart. no. 11, inv. no. 1417.

73 Sbírka zákonů a nařizení státu československého, 1928, částka 60, Vládní nařízení č. 174/1928 Sb.

74 SOkA Jihlava, Městská správa Jihlava od roku 1849, presidial registry, cart. no. 9, inv. no. 1090.

75 SOkA Jihlava, Městská správa Jihlava od roku 1849, official books, inv. no. 17.

76 For more detail, see: PALÁNOVÁ, Vznik československé republiky, 211-233. On the issue of eliminating German dominance in public institutions, see: PALÁNOVÁ, Česko-německé vztahy, 117-131. 
the Ministry of the Interior of 21 May 1919 at the request of the Administrative Commissioner, and thus they took place only on 26 September $1919 .{ }^{77}$ What is interesting is the justification for the postponement of the elections by the Jihlava Administrative Commissioner:

In the month of January, when submitting a request for the postponement of the elections in the Town of Jihlava to the National Assembly, I was thinking only of the benefit of the local Czechs... The situation I mentioned at the time as the reason for the postponement of the elections has not yet undergone the desired changes, since especially in the case of authorities - the governor's office, the courts, the financial directorate, the post and tax office, and the tobacco factories - many of the positions are still occupied by officials of German nationality, so the centre of the hope of a positive election result in favour of the Czech Jihlava minority has not yet shifted at all. ${ }^{78}$

Representatives of all German political parties publicly protested against the postponement of the elections, even calling a demonstration on 29 May in the Jihlava main square. The postponement of the municipal elections was criticized at the meeting of the Administrative Committee on 6 June 1919 by the German members of the Administrative Committee, who asked for the withdrawal of the postponement procedure, but it was not surprising that they did not succeed with their proposal. ${ }^{79}$

While the longer preparation time did help the Czech activists, a fundamental change could not take place. In total, 8,015 (62.64\%) votes for the German representatives were cast in the municipal elections, with 4,317 (33.77\%) for the Czech representatives and $464(3.63 \%)$ for representatives of the Jewish minority. Based on these results, the Germans gained 27 mandates in the town council, the Czechs 14 and the Jews one. ${ }^{80} \mathrm{In}$ reaction to this, the $C$ zech activists filed a protest against alleged election frauds, which the provincial political authorities recognized as incompatible with regular elections (especially fundamental problems with the lists of voters). ${ }^{81}$ Consequently, the results of the first post-war municipal elections in Jihlava were annulled. This triggered a wave of protests from the German representatives, who failed to ensure that the results of the elections be taken into account in the composition of the Administrative Committee. Less than a month after the publication of the annulment of the municipal election results, the traditional celebration of the summer solstice (Sonnwendfeier) took place in Jihlava on 23 June 1920, which turned into an uncontrollable manifestation, resulting in two dead and nine injured Czech soldiers and two injured German demonstrators. ${ }^{82}$

Although the new elections, held on 26 September 1920, brought about a strengthening of the Czech political parties ( $45 \%$ of the votes cast), they still did not gain a majority. Objections from the $C$ zech side were raised about the running of the elections, but due to the generality and lack of clarity of the objections, the election of the municipal council was confirmed. For the German politicians this was yet another

77 SOkA Jihlava, Městská správa Jihlava od roku 1849, political registry, inv. no. 1573.

80 PALÁNOVÁ, Česko-německé vztahy, 128.

81 SOkA Jihlava, Městská správa Jihlava od roku 1849, presidial registry, cart. no. 10, inv. no. 1273.

82 SVĚRÁK, Nikdy zcela neodešli. 
election that continued a series of injustices, with the Czechs doing everything they could to get the maximum number of votes. ${ }^{83}$ On 4 December 1920, the moderate German Social Democrat Othmar Oberrenner was elected mayor. Moreover, in the case of statutory towns, the election had to be confirmed by the Czechoslovak government, which, however, took its time, so Oberrenner did not officially enter the mayor's office until five months later - in April 1921. Teacher and national activist Josef Výborný (1889-1982) became the first deputy mayor, soon initiating negotiations on the merging of the large Czech municipality of Dřevěné Mlýny with Jihlava.

What was the purpose of this move? The merging of Jihlava and the immediately adjacent municipality of Dřevěné Mlýny had already been seriously discussed before the First World War. In the second half of the nineteenth century, this originally small farming community began to industrialize rapidly owing to the proximity of the railway, resulting in a population increase. Due to the Jihlava main railway station, located in the Dřevěné Mlýny land register, and the gradual urban development, the administrative merger of the municipalities presented itself as the first option. As early as 1909, a joint committee was formed from the representatives of the two municipalities to study the possibilities of the merger, taking an interest in similar recent cases (the merger of Koloredov with Místek, or the municipality of Wilten with the provincial capital of Innsbruck). ${ }^{84}$ Despite the financial question marks, on 12 January 1910 the Dřevěné Mlýny Municipal Committee, together with the Jihlava Municipal Committee, decided to merge into one municipality. On 4 March 1912 the Moravian Provincial Committee made the decision to reject the request as the merger of Jihlava with Drevěné Mlýny contravened the provision of Section 1 of the Jihlava Municipal Statute of 1874. Jihlava wanted to unblock the situation and in April 1912 the town council proposed an amendment to the relevant section of the statute, informing the Viceregency of this in an official letter dated 31 May 1912. The Provincial Committee drew up the corresponding draft of the law on the merger of Jihlava and Dřevěné Mlýny, submitting it to the Moravian Land Diet on 10 February 1914. However, the draft of the Land Law was never discussed: on 28 February 1914 the Land Diet was adjourned and did not meet again during the war. ${ }^{85}$

Immediately in the post-war period the issue started to be discussed again, first in the administrative committees. What was unpleasant was that the Administrative Committee of Dřevěné Mlýny, set up on 14 January 1919, unanimously withdrew its initial consent to the implementation of the merger, despite the fact that the Czechs had a majority representation there. On 3 May 1919, on the other hand, it supported the proposal of some citizens of the municipality of Hruškové Dvory to merge the two municipalities, on the grounds that the developments of the two municipalities were getting closer to each other, that the municipalities were well connected by means of a communication network, and that their economic situation was similar. However, the political authorities had no interest in this "bottom-up" initiative. By a decree of 23 December 1919, the Ministry of the Interior did not endorse this activity, rejecting the request for the merger on the grounds that "the local situation is not such as to

83 See the investigation of the interpellations of deputies Rudolf Jung and Siegfried Taub. SOkA Jihlava, Městská správa Jihlava od roku 1849, presidial registry, cart. no. 10, inv. no. 1295. SOkA Jihlava, Městská správa Jihlava od roku 1849, presidial registry, cart. no. 12, inv. no. 1524.

84 SOkA Jihlava, Městská správa Jihlava od roku 1849, political registry, inv. no. 1595.

85 SOkA Jihlava, Městská správa Jihlava od roku 1849, political registry, inv. no. 1595. 
justify the merger of the two municipalities and, moreover, the population of Hruškové Dvory does not want the merger". ${ }^{86}$

However, the intention of merging Dřevěné Mlýny with Jihlava started to be prepared again at least from the beginning of 1923. By a letter dated 26 January 1923, two members of the Dřevěné Mlýny Municipal Council asked for a meeting to be called on this point because they had heard that "respected officials are working on it". At the meeting, held on 17 March 1923, the Dřevěné Mlýny Municipal Council once again withdrew its consent to merge with Jihlava, claiming that it objected to the resumption of the merger action. In May 1923, the representatives of the municipal authority intended to personally convey their stance at a meeting with the District Governor, with activities against the merger process culminating in August 1923 when the municipality hired a legal advisor to find any way to make the process impossible. ${ }^{87}$ At the same time, the representatives of Dřevěné Mlýny also reiterated their clearly negative stance in a memorandum addressed to the Czechoslovak government, in which they questioned the government's intention, claiming that no one in this municipality wanted the merger - neither the Czechs, nor the Germans. ${ }^{88}$

However, all protests were futile, as was holding a public protest meeting on 10 September 1923 and sending special comments to the Ministry of the Interior against the intention of the merger. On 25 October 1923, the Ministerial Council issued Resolution No. 24801/23, where the government authorized the merger of Jihlava and Dřevěné Mlýny, not taking into account the comments of the opponents of the action, which took ten lines to enumerate in the protocol. The Ministry of the Interior issued its own decree concerning the merger a day later. ${ }^{89}$ The resignation and aftertaste of the forced merger of the municipalities is evident from the last protocol of the meeting of the municipality of Dřevěné Mlýny on 13 November 1923, in which the entire municipal council resigned in one sentence. ${ }^{90}$ Everything took place in accordance with the decree of the provincial political authorities of 12 November 1923 on the dissolution of the Jihlava and Dřevěné Mlýny municipal councils and the establishment of an Administrative Commissioner for the merged municipalities of Jihlava.

However, even in the case of the Jihlava Municipal Government, most were not in favour of the merger. At the meeting on 17 May 1923, the proposal to merge the two municipalities was discussed and the situation reached a stalemate. After a lively discussion, the proposal turned out to have more opponents than supporters among the Jihlava representatives (of the 41 people present, only thirteen were in favour of the merger, all nineteen German representatives were against, and nine communist representatives across the national spectrum abstained), but neither in the municipal government nor in the town council did any of the options gain the support of the majority. ${ }^{91}$ The district political authority also tended to take a negative view of the action. In an official letter dated 29 May 1923 and addressed to the provincial political authority, it stated directly that the merger was problematic for both economic and

86 SOkA Jihlava, Archiv obce Dřevěné Mlýny, cart. no. 1, inv. no. 38.

87 SOkA Jihlava, Archiv obce Dřevěné Mlýny, book no. 4. SOkA Jihlava, Městská správa Jihlava od roku 1849, political registry, inv. no. 1595.

88 SOkA Jihlava, Městská správa Jihlava od roku 1849, political registry, inv. no. 1595.

89 SOkA Jihlava, Archiv obce Dřevěné Mlýny, cart. no. 1, inv. no. 38.

90 SOkA Jihlava, Archiv obce Dřevěné Mlýny, book no. 4.

91 SOkA Jihlava, Městská správa Jihlava od roku 1849, presidial registry, cart. no. 11, inv. no. 1409. 
political reasons. It considered Jihlava's economic situation to be dismal due to the longstanding national and social dissension, which was best demonstrated by the amount of the municipal surcharge, at a level of $1000 \%$ (!!!). This, together with a number of municipal taxes, threatened the existence of trade and industry in the town. The inhabitants of Dřevěné Mlýny would therefore suffer significantly from the merger. Moreover, the Dřevěné Mlýny working-class families were largely communist-minded, which would only strengthen the communists in the Jihlava Town Hall and "although they [were] mainly the so-called Czech communists, they [were] worse than nationalist Germans". ${ }^{22}$ Not even the interpellation of the deputies Franz Pittinger and Emmerich Radda in late November 1923 helped with the issue, an interpellation in which they stated that the whole merger action had taken place only on the initiative of several Czech fanatics who wished to make Jihlava Czech. From the reply of the prime minister, Antonín Švehla, it was evident that nothing could change the final decision of the government anymore and that Švehla considered the merger beneficial, especially in a situation where the population of Dřevěné Mlýny was guaranteed the special management of municipal property and for twenty years also set municipal surcharges differently. ${ }^{93}$

It was only after the merger of Dřevěné Mlýny with Jihlava that the ratio of the national forces in the town was definitively changed and the strength of the two camps evened out. The path to the new municipal elections was surprisingly long even in this favourable situation for the local Czechs, lasting a full sixteen months, which was de facto illegal (according to $\S 3$ of Act No. 117/1921 Sb., the elections were to take place no longer than one year after the establishment of an administrative committee for the merged municipalities). This period was used by Administrative Commissioner Výborný to fully implement his ideas for running the town, which caused waves of resentment with not only the local Germans, but even the Czechs raising objections. Výborný was repeatedly accused of absolutist and chauvinistic practices, but he stood his ground until the new municipal elections. ${ }^{94}$

Výborný led the town to new municipal elections, which took place on Sunday 22 March 1925. Only there did the Czech political parties achieve a historic victory they received one-third more votes than in the previous municipal elections - and could thus legally control the municipal government, including the post of mayor. The increase in the number of $C z e c h$ votes was so great that the German parties expressed their right to question the fairness of the elections. Even the Czech communists referred to the elections as "Turkish", as elections that could only embarrass the Czechoslovak democracy, as the victory was achieved with false votes and the votes of the dead. Out of a total of 42 possible mandates, 26 were won by Czech parties and only 16 by German parties, while the Jews did not gain a single mandate. After a constituent meeting of the municipal government on 4 July 1925, Social Democrat and advocate JUDr. Rudolf Veverka was put in charge of the town. Josef Výborný was unsuccessful in the mayoral election and the last German mayor, Otmar Oberrenner, became the first deputy. With the arrival of the new government of the town, the situation in Jihlava stabilized. ${ }^{95}$

92 SOkA, Okresní úřad Jihlava, presidial registry, inv. no. 6596.

93 Interpelace poslanců Pittingera, dra Raddy a druhů celé vládě o nuceném sloučení obce Dřevěných Mlýnů s Jihlavou z 29. listopadu 1923.

94 SOkA Jihlava, Městská správa Jihlava od roku 1849, presidial registry, cart. no. 11, inv. no. 1472.

95 PALÁNOVÁ, Česko-německé vztahy, 126. 
A small town on the national border: The case of Zábřeh ${ }^{96}$

As early as late August, a 23-member North Moravian National Committee, which represented a relatively large nationally mixed territory of northwest Moravia, became active in Zábřeh under the leadership of the local national activist Joža Malý. Immediately after the proclamation of the Czechoslovak state, the National Committee took control of all state offices in the seat of the political district without any major problems. ${ }^{97}$ In contrast to the above-mentioned cases, the District Governor, Heinrich von Strobach, was quickly retired as early as 9 December 1918 and replaced by a Czech. The town hall in Zábřeh, like in many other towns in mixed-language areas, had long been controlled by members of the municipality who, in the process of national crystallization, mostly claimed German nationality. The takeover of the Zábřeh municipal authority did not take place until mid-November. On 14 November 1918, a deputation of the National Committee came to the mayor of the town, asking him to hand over the administration of the town immediately. The mayor wanted to take three days to think about it, but eventually announced his resignation under duress. In the afternoon, at an emergency council meeting, all its members resigned. On the same day, members of the municipal committee addressed a letter to the District Governor's Office in Zábřeh, stating that they had resigned only because the National Committee had put them under pressure and that they wanted to maintain peace and order in the town. ${ }^{98}$ The District Governor's Office appointed an Administrative Commissioner - the judge of the local district court, and an Administrative Committee of 12 members (eight Czech and four German representatives). This power transfer in the town took place, in the words of a reporter from the District Governor's Office, "perfectly peacefully".99

Immediately after taking power, the Administrative Commissioner, in cooperation with the National Committee, began to prepare a plan to ensure an optimal constellation for regular municipal elections. In the case of Zábřeh, the local National Committee expressed it quite explicitly:

According to the last census, the Czechs were a smaller than one-third minority. With the coup d'état, the ratio has changed in our favour only slightly. We have taken control of the town, requesting the dissolution of the municipal council and the establishment of an Administrative Committee, which includes 8 of us alongside 4 Germans. For the future, however, we want to secure a majority by merging the adjoining Czech village of Krumpach. But even after this merger our majority will be weak, if not dubious. We must therefore make every effort to strengthen our position. ${ }^{100}$

The main measure under consideration was to merge the town of Zábřeh with the neighbouring village of Krumpach, which was a relatively large municipality with a large

96 The following section is written based on the study: POPELKA, Mocenský transfer, 87-111.

97 FILIP, Severomoravský národní výbor, 377-382.

98 Státní okresní archiv Zábřeh (hereinafter SOkA Šumperk), Okresní úřad Zábřeh, cart. no. 97. SOkA Šumperk, Archiv města Zábřeh, inv. no. 683, sign. B-I-19.

99 SOkA Šumperk, Okresní úřad Zábřeh, cart. no. 97.

100 SOkA Šumperk, Severomoravský národní výbor Zábřeh, cart. no. 1, inv. no. 1. 
Czech majority that was connected with Zábřeh by the residential development and a significant part of its inhabitants finding employment in the Zábřeh textile mills.

The intention to merge Zábřeh and Krumpach was first discussed at a meeting of the North Moravian National Committee on 27 November 1918. The Krumpach Municipal Committee discussed the question of a merger with Zábřeh as early as 29 November and reached a positive stance. ${ }^{101}$ Even at this stage, the German side also registered the merger efforts, stating that if Zábřeh and Krumpach were to be merged, the fate of the, until then, German town would be sealed forever. The intention therefore encountered resistance from the German representatives in the Zábreh Administrative Committee, where it was discussed on 3 December 1918, but not even the two German protest petitions sent to the Moravian Viceregency achieved anything. ${ }^{102}$

What is very interesting, however, is that at the same time the representatives of Rudolfov, a small municipality located in the immediate vicinity of Zábřeh, repeatedly requested to merge with Zábřeh of their own accord, without anyone persuading them of the potential advantages of the merger. In their case, however, neither the members of the Zábřeh Administrative Committee nor the National Committee were interested in the merger. The reason was given very openly by the Administrative Commissioner himself: "Since Rudolfov is not nationally safe, the matter is postponed until after the regular municipal elections". ${ }^{103}$ The merger of Rudolfov with Zábřeh did not take place until 1949, naturally in an already completely different reality.

Although the question of the merger of Zábřeh and Krumpach began to be actively addressed by the Moravian Viceregency as early as the beginning of 1919, the closer the possible date of the municipal elections, the more the nervousness of the members of the still-functioning North Moravian National Committee grew. As early as 20 March 1919 , i.e. at a hot stage in the run-up to the municipal elections, the representatives of the National Committee wrote in a telegram addressed to the seat of the Moravian Viceregency that if the merger did not take place before the municipal elections, there was a risk of "irreparable damage in the national direction". Fortunately for the local Czech national activists, in the political district of Zábřeh the municipal elections were ultimately postponed to 15 June 1919, and in the case of the municipalities where the merger was to take place, the day of the elections was to be rescheduled to an even later date. This step was clearly intended to ensure that the merger of the municipalities would be reflected in the election results.

In late May 1919, the Ministry of the Interior planned to resolve the whole merger issue. For the next three months, however, it had to deal with objections to the merger, not only from the German side, but also, surprisingly, from some Krumpach citizens who made the accusation towards the members of the National Committee that the consent of the Krumpach Municipal Committee in November had been given under duress. The Ministry of the Interior definitively approved the merger by a decree of 20 September 1919. On 9 November 1919, the last meeting of the Krumpach Municipal Council took place, and the following day the provincial political authority dissolved the local municipal council and appointed a new Administrative Committee of the merged Zábřeh, whose aim was to lead the municipality to the elections. ${ }^{104}$

101 SOkA Šumperk, Severomoravský národní výbor Zábřeh, cart. no. 1, inv. no. 1.

102 SOkA Šumperk, Archiv města Zábřeh, inv. no. 683, sign. B-I-19.

103 SOkA Šumperk, Severomoravský národní výbor Zábřeh, cart. no. 1, inv. no. 1.

104 SOkA Šumperk, Okresní úřad Zábřeh, cart. no. 97. 
The Administrative Committee carried out this task without delay. The District Governor's Office set the election date for Sunday 8 February 1920, and by the end of the year the lists of candidates were drawn up. A total of eleven political parties and groups, five of which were German and six Czech, competed for the voters' favour. The municipal elections themselves marked the end of German control over the town hall. In the 36-member municipal council, the Czech parties gained a total of 22 mandates, while the German parties gained only 14 . The result enabled a smooth election of the mayor from the ranks of the local Czechs, with National Democrat Richard Indra taking the post. ${ }^{105}$

The representatives of the Czech and German press subsequently interpreted the results of the first municipal elections under Czechoslovakia in their own way. According to the German periodical Deutsche Wacht, the 14 mandates obtained clearly demonstrated the German character of the town, with the overall result being influenced only by the calculated merger with Krumpach. The reason was that in the town itself the Czechs had gained only 12 mandates, while the Germans had gained the above-mentioned 14. In contrast, Moravský Sever emphasized that despite the desperate German efforts, the Czechs had gained a majority in the elections and that Zábřeh was Czech. The Catholic-oriented periodical Nová Severní Morava also assessed the results of the municipal elections through its own lens, considering the municipal elections as proof that Zábřeh was Czech and Catholic. ${ }^{106}$ In this context, however, it is interesting that none of the published reactions mentioned the consequences of the new electoral law with regard to the democratization of the municipal elections. ${ }^{107}$

\section{Conclusion}

The presented probe into the problem of the power transition in the municipal authorities of five Moravian towns after the First World War showed a number of symptomatic features related to the assertion of the domain of the forming Czechoslovak power at the local level.

From the point of view of the mechanism for taking over the municipal authorities, the establishment of an alternative power network of national committees, which quickly gained control over the state offices, was essential. These extraordinary bodies, formed spontaneously in the short period of the last days of the Austro-Hungarian Monarchy, were significantly active in relation to the municipal and town self-governments. In an effort to bring the municipal councils and, as a result, also the affairs at the local level under control, the national committees initiated the resignation of the existing municipal authorities, which, in the surveyed cases, took place involuntarily. In all the surveyed cases the takeover of key local state offices took place even before the forced suspension of the municipal councils.

In all cases, in accordance with the legal order, the new leadership of the Viceregency appointed administrative commissioners who were put in charge of administrative committees. According to $\S 107$ of the Moravian Municipal Code, the administrative committees were only advisory bodies, and thus the administrative commissioner was not bound by their opinion. Those appointed as administrative commissioners

105 SOkA Šumperk, Archiv města Zábřeh, cart. no. 129.

106 POPELKA, Mocenský transfer, 107.

107 Deutsche Wacht, 1920 (13 February), vol. 20, no. 7, pp. 1-2. Moravský Sever, 1920 (13 February), vol. 20, no. 9, pp. 1-2. Nová Severní Morava, 1920 (14 February), vol. 2, no. 7, p. 1. 
in ethnically mixed municipalities were usually already proven Czech politicians or national activists. ${ }^{108}$ The number of members of the administrative committees varied, and in most cases not even an odd number was demanded. In the individual towns and municipalities, the committees were appointed in such a way that they already secured Czech supremacy at this point, or at least that they brought a parity representation of both nationalities. The reason was simple: On the one hand, the German population did not identify with the idea of a Czechoslovak state and, on the other, in many nationally mixed towns there was frustration among the Czechs about the impossibility of winning the municipal elections. The administrative committees were composed of representatives of the local political parties, experts and national activists. German parties could also nominate their representatives for the administrative committees, often reaching for proven old hands of municipal politics or local public life. However, the share of the representatives of the two main nationalities in the administrative committees did not reflect the statistical share of nationalities according to the previous census, or in many cases even the real national situation, but rather showed the current distribution of power in the municipality. ${ }^{109}$

In Moravia, the removal of whole municipal councils or a part of their members and the appointment of administrative commissioners took place mostly from late October until December 1918. The resigning municipal representatives often appealed against their suspension to the provincial political or self-governing bodies, but, in the reality of the coup d'état, this was doomed to failure in advance. The administrative commissioners and their committees thus became the legal, albeit provisional, bodies of municipal authority, running the municipal affairs until the next municipal elections. In the majority of municipalities this occurred as early as June 1919, when the first post-war municipal elections (from the surveyed towns only in Olomouc and Brno) took place in most of the Bohemian Lands. In some municipalities, however, the elections were postponed. These were not only areas whose fate was still under discussion (e.g. the Cieszyn or Hlučín regions), but also municipalities where the municipal borders were expected to change (due to the merging of municipalities) or where problems arose that would complicate the smooth running of the elections. In these cases, the work of the administrative committees could be considerably protracted (e.g. in Jihlava or Moravská Ostrava it was a matter of years).

Preparations for the first municipal elections in the new Czechoslovakia were not taken lightly. They were intended to show Czech superiority in sensitive mixedlanguage areas and to secure control over important town halls of nationally mixed towns. In all five surveyed cases, merging the town itself with a suburban municipality or municipalities became the main means of achieving this objective. From the point of view of a country-wide comparison, it can be said that the merging of municipalities mainly concerned Moravia. While, in the first ten years after the war, 44 municipalities were merged in Bohemia, 9 municipalities in Silesia and 60 municipalities in Slovakia (with no such processes taking place in Carpathian Ruthenia), a total of 101 municipalities

108 E.g. in Olomouc Richard Fischer, in Znojmo Vilém Veleba, in Jihlava František Hovůrka, in Moravská Ostrava Jan Prokeš, in Hodonín Eduard Krajíček, in Zábřeh Joža Malý.

109 E.g. in Brno 16 Czechs and 8 Germans, in Moravská Ostrava 22 Czechs and 7 Germans, in Znojmo 12 Czechs, 10 Germans and 2 Jews, in Opava 14 Czechs, 12 Germans and 2 Jews, in Olomouc 16 Czechs and 8 Germans, in Jihlava 12 Czechs and 12 Germans, in Lipník 12 Czechs and 3 Germans, in Zábřeh 8 Czechs and 4 Germans. 
were merged in Moravia, creating 46 new municipalities. These statistics show that in Moravia the issue of merging municipalities was particularly important. ${ }^{110}$

The merger process affected municipalities in large residential agglomerations as well as in towns that were perceived as sensitive by the Czech national activists. Although this process was officially presented as an effort to rationalize the municipal authorities, within the framework of municipal mergers such constellations of municipalities were always chosen as to secure the majoritization of the Czech electorate. The merging of municipalities thus turned out to be an important strategy by which to ensure the election of such a municipal council as would guarantee the loyalty of the majority of its members to the new republic and secure the dominance or appreciable strengthening of the Czech ethnic group in self-governing bodies. The issue of the new administrative arrangement in the case of larger urban agglomerations, not only in Moravia, but also in Bohemia, was of fundamental importance - this concerned mainly Prague, Plzeň, Brno, Olomouc and Ostrava, but also Liberec, České Budějovice, Jihlava and Znojmo.

In many residential agglomerations, the purposeful merger of suburban municipalities to the town centre had already been under consideration before the First World War. This was generally due to practical economic, transportation and administrative aspects. However, the town halls usually resisted this trend with respect to the national situation, as the German representatives feared losing their influence in the municipal authorities. Therefore, no major merger action took place in the Bohemian Lands before the First World War.

From the surveyed localities, the fastest merging process took place in the Brno and Olomouc residential agglomerations, where the relevant laws were adopted as early as April 1919 and the municipal elections were held identically in June 1919. In the nationally sensitive Zábřeh, the merger took place in early November 1919 and the municipal elections in February 1920. In the Ostrava agglomeration, the merger process was significantly complicated by the fact that the given municipalities were located on the territory of two historical lands; in addition, the fate of Cieszyn Silesia was uncertain until as late as 1920. The creation of Velká Ostrava was carried out on a smaller scale and only with a long delay at the turn of $1923 / 1924$, and the first post-war municipal elections were held in Velká Ostrava as late as November 1924. In Jihlava they were already on the verge of merging the municipalities before the First World War, but for a number of reasons the merger was carried out with a delay and despite the great resistance of both the German population and the inhabitants of the merged municipalities only in 1923. The subsequent municipal elections were held as late as March 1925.

In most cases, the German members of the administrative committees as well as German activists and the local press objected to the post-war merger plans, but to no avail. At the level of the administrative committees, they were always overruled by the bloc of Czech representatives, and when appealing to a higher self-governing body or, more precisely, to the bodies of political administration, their arguments were not considered to be sufficiently valid. However, this was to be expected given the interests of the political bodies of the newly created state.

At the same time, the cases described show that the idea of merging municipalities was not always met with the understanding of the municipalities which the project

110 Deset let Československé republiky. Vol. I., 301. 
concerned, or that it provoked opposition from the local citizens or associations. This is clear from the circumstances of the mergers in the cases of Jihlava and Zábreh, where the mergers took place under pressure. In the case of the Olomouc region, shortly after the merger some of the municipalities asked for renewed independence, as they were disillusioned with the operation of the Municipal Authority of "Velká Olomouc". In some cases, both associations and the citizens themselves (e.g. Vítkovice) opposed the merger. Interestingly, there was also a "bottom-up" initiative in the post-war climate, calling for a rational merging of municipalities (the Ostrava, Zábřeh and Jihlava regions). However, this spontaneous activity was not accepted by the self-governing bodies if it did not correspond with the national interests.

In the surveyed cases, the results of the first municipal elections show a high degree of discipline of the German voters, where even in adverse conditions the German parties gained a decent representation in the newly elected self-governing bodies. The new municipal councils showed a significant degree of personnel discontinuity compared to the previous ones. Most of the newly elected representatives - even the German ones - were elected to their respective municipal councils for the first time. The introduction of universal suffrage, combined with the process of municipality mergers, thus seems to have fundamentally changed the municipal politics of the surveyed towns.

The long-standing efforts of the Czech activists at the municipal level, which resulted in the so-called battle for the town halls in Moravia, allowed the Czech representatives to win this fight in mixed areas after the creation of Czechoslovakia. However, it did nothing to improve the complex relations in municipalities as a result of the nationalization of the society. On the German side, this process created the same sense of injustice that had been experienced by the Czech national activists before the First World War. However, this unfavourable development for the German ethnic group did not trigger any waves of exodus. The existential conditions in Czechoslovakia were, after all, more favourable than in Germany or German Austria. ${ }^{111}$ And, what is most important, in the majority of cases the Germans still felt rightfully at home there.

\section{BIBLIOGRAPHY}

\section{Primary sources}

Státní okresní archiv Jihlava, Městská správa Jihlava, presidial registry

Státní okresní archiv Jihlava, Městská správa Jihlava od roku 1849, official books

Státní okresní archiv Jihlava, Městská správa Jihlava od roku 1849, political registry

Státní okresní archiv Jihlava, Archiv obce Dřevěné Mlýny

Státní okresní archiv Jihlava, Okresní úřad Jihlava, presidial registry

Státní okresní archiv Olomouc, Archiv města Olomouce, presidial registry

Státní okresní archiv Olomouc, Archiv města Olomouce, register 1920-1940

Státní okresní archiv Olomouc, Archiv města Olomouce, books

Archiv města Ostrava, Okresní národní výbor Moravská Ostrava

Archiv města Ostrava, Okresní úřad Moravská Ostrava

Archiv města Ostrava, Archiv města Moravská Ostrava - new registry, 1919-1923

Státní okresní archiv Šumperk, Severomoravský národní výbor Zábřeh

Státní okresní archiv Šumperk, Archiv města Zábřeh

Státní okresní archiv Šumperk, Okresní úřad Zábřeh

111 HÖBELT, Das Erste Republik Österreich, 19. 
BOHÁČ, Antonín. Národnostní mapa republiky Československé. Podrobný popis národnostních hranic, ostrovů a menšin. Praha: Národopisní společnost československá, 1926.

BOHÁČ, Antonín. Vývoj Čechův a Němcův na Moravě. In: Časopis Matice moravské, 1908, vol. 32, pp. 270-306, 366-389.

Deset let Československé republiky. Vol. I. Praha, 1928.

Deset let práce na olomoucké radnici 1918-1928. Olomouc, 1928.

Deutsche Wacht, 1920.

FISCHER, Richard. Česká účast při obecních volbách v Olomouci před prevratem. Olomouc, 1932.

Lidové noviny, 1920.

MOLISCH, Paul. Die sudetendeutsche Freiheitsbewegung in den Jahren 1918-1919. Wien;

Leipzig, 1932.

Mährisches Tagblatt, 1919.

Moravsko-slezský deník, 1918.

Morauský Sever, 1920.

MINÁŘ, Jaroslav (ed.). Paměti okresního národního výboru olomouckého. Olomouc, 1919.

Nová Severni Morava, 1920.

Občanské noviny, 1920.

Sbírka zákonů a nařizení státu československého. Praha, 1919.

Sbírka zákonů a nařízení státu československého. Praha, 1928.

Staatsgesetzblatt für den Staat Deutschösterreich, 1918.

Statistický lexicon obcí v Republice československé. Vol. II. Morava a Slezsko. Praha, 1924.

Statistický lexicon obcí v zemi Moravskoslezské. Praha, 1935.

\section{Secondary sources}

BADER-ZAAR, Brigitta. Demokratisierung des Wahlrechts. In: KRIECHBAUMER, Robert MAIER, Michaela - MESNER, Maria - WOHNOUT, Helmut (eds.). Die junge Republik. Österreich 1918/1919. Köln; Weimar; Wien: Böhlau, 2018, pp. 101-112.

BARTOŠ, Josef - SCHULZ, Jindřich - TRAPL, Miloslav. Historický místopis Moravy a Slezska 1848-1960. Vol. 3, 4, 10. Ostrava: Profil, 1972, 1974, 2004.

BARTOŠ, Josef - TRAPL, Miloš. Dějiny Moravy 4. Svobodný stát a okupace. Brno: Muzejní a vlastivědná společnost, 2004.

BRUCKMÜLLER, Ernst. Österreichische Geschichte. Wien; Köln; Weimar: Böhlau Verlag, 2019.

BURIAN, Zdeněk. Brněnští Němci a teritoriálně-politické proměny brněnského jazykového ostrova. Master's thesis, Masaryk University, 2020.

COHEN, Gary B. Nationalist Politics and the Dynamics of State and Civil Society in the Habsburg Monarchy, 1867-1914. In: Central European History, 2007, vol. 40, pp. 441-478.

EGRY, Gábor. Negotiating Post-Imperial Transitions. Local Societies and Nationalizing States in East Central Europe. In: MILLER, Paul - MORELON, Claire (eds.). Embers of Empire: Continuity and Rupture in the Habsburg Successor State after 1918. New York; Oxford: Berghahn Books, 2019, pp.15-42.

FASORA, Lukáš - ŠTĚPÁNEK, Václav. Dějiny Brna 6. Předměstské obce, Brno: Statutární mesto Brno, 2017, 1245.

FILIP, Zdeněk. Severomoravský národní výbor 1918-1920. In: JANÁK, Jan (ed.). Ústřední moc a regionální samospráva. Brno; Břeclav: SOA, 1995, pp. 377-382.

HAAS, Hans. Konflikt při uplatňování nároků na právo sebeurčení: od habsburského státu k Československu - Němci v českých zemích v letech 1918 až 1919. In: MOMMSEN, Hans KOVÁČ, Dušan - MALÍř, Jiří - MARKOVÁ, Michaela (eds.). První světová válka a vztahy mezi Čechy, Slováky a Němci. Brno: Matice moravská, 2000, pp. 113-177.

HÁJEK, Martin. Olomoučtí Němci 1918-1938. PhD. diss. Palacký University Olomouc, 2018. HLAVAČKA, Milan. Der Zerfall des Reiches von Prag aus gesehen. Die Tschechen und die Doppelmonarchie. In: BÉHAR, Pierre - PHILIPPOFF, Eva (eds.). Von der Doppelmonarchie 
zur Europäischen Union. Österreichs Vermächtnis und Erbe. Hildesheim; Zürich; New York: Georg Olms Verlag, 2011, pp. 93-106.

HLAVAČKA, Milan. Zlatý věk české samosprávy. Samospráva a její vliv na hospodářský, sociální a intelektuální rozvoj Čech 1862-1913. Praha: Libri, 2006.

HÖBELT, Lothar. Das Erste Republik Österreich (1918-1938). Das Provisorium. Wien; Köln; Weimar: Böhlau Verlag, 2018.

HÖHNE, Steffen (ed.). Zusammenbruch, Trauma, Triumph. Das Epochenjahr 1918 und sein Nachleben in Zentral-, Ostmittel- und Südeuropa. Wiesbaden: Harrassowitz Verlag, 2020.

HUDEK, Adam - KOPEČEK, Michal - MERVART, Jan. Čecho/slovakismus. Praha: NLN, 2019.

JAŠŠ, Richard - FŇUKAL, Miloš. The German Language Islands of Brno, Olomouc and Jihlava during German-Austrian Irredentism in the Autumn 1918. In: Moravian geographical reports, 2009, vol. 17, pp. 40-49.

JIŘÍK, Karel. Státní převrat na Ostravsku v roce 1918 ve vzpomínkách pamětníků. In: Ostrava. Př́spěvky k dějinám a současnosti Ostravy a Ostravska, 1999, vol. 19, pp. 402-427.

JUDSON, Piere M. Habsburg. Geschichte eines Imperiums 1714-1918. München: C. H. Beck, 2017.

JUDSON, Pieter M. Welcher Zerfall? Welcher Triumph? Imperialistische Praktiken, gesellschaftliche Werte, regionale Identität, 1918. In: HÖHNE, Steffen (ed.).

Zusammenbruch, Trauma, Triumph. Das Epochenjahr 1918 und sein Nachleben in Zentral-, Ostmittel- und Südeuropa. Wiesbaden: Harrassowitz Verlag, 2020, pp. 15-26.

KESSLER, Vojtěch. Češi a Němci v roce jedna. Úvahy nad postoji a možnostmi Němců v českých zemích mezi 28. ř́jnem 1918 a 4. březnem 1919. In: Moderní dějiny/Modern History, 2018, vol. 26, pp. 143-164.

KING, Jeremy. Budweisers into Czechs and Germans: A local History of Bohemian Politics 1848-1948. Princeton: Princeton University Press, 2002.

KLADIWA, Pavel - GAWRECKI, Dan - KADLEC, Petr - POKLUDOVÁ, Andrea - POPELKA, Petr. Národnostní statistika v českých zemích 1880-1930. Mechanismy, problémy a důsledky národnostní klasifikace. Praha: Nakladatelství Lidové noviny, 2016.

KLADIWA, Pavel - POKLUDOVÁ, Andrea - KAFKOVÁ, Renata: Lesk a bída obecních samospráv Moravy a Slezska 1850-1914. Vol. II./1. Ostrava: Ostravská univerzita, 2008.

KLADIWA, Pavel. Leska bída obecních samospráv Moravy a Slezska 1850-1914. Vol. I. Vývoj legislativy. Ostrava: Ostravská univerzita, 2007.

KLEČACKÝ, Martin. Převzetí moci. Státní správa v počátcích Československé republiky 1918-1920 na příkladu Čech. In: Český časopis historický, 2018, vol. 116, no. 3, pp. 693-732.

KOCHNE, Ernst Rudolf. Die unbeabsichtigte Republik. Deutschösterreich 1918-1920. Hamburg: Verlag Dr. Kovač, 2020.

KOELTZSCH, Ines - KONRÁD, Ota. From "Islands of Democracy" to "Transnational Border Space": State of the Art and Perspectives of the Historiography on the First Czechoslovak Republic since 1989. In: Bohemia. Zeitschrift für Geschichte und Kultur der böhmischen Länder, 2016, vol. 56, pp. 285-327.

KONTNY, Johannes. Herrschaftssicherung an der Peripherie? Die Transformation der städtischen Selbstverwaltung in Eupen und Znojmo/Znaim nach dem Ersten Weltkrieg (1918-1922). In: Bohemia. Zeitschrift für Geschichte und Kultur der böhmischen Ländern, 2016, vol. 56, pp. 381-405.

KRLÍN, Jan. Výměny úředníků státní správy v českých zemích v letech 1918-1920. In: Paginae historiae, 1998, vol. 6, pp. 210-253.

KUČERA, Rudolf (ed.). Muži ř́ijna 1918. Osudy aktérů vzniku Republiky československé. Praha: Masarykův ústav AV CR, 2011.

MALÍŘ, Jiří - ŘEPA, Milan. Morava na cestě $k$ občanské společnosti. Brno: Muzejní a vlastivědná společnost, 2018.

MALÍŘ, Jiří et al. Biografický slovník poslanců moravského zemského sněmu v letech 18611918. Brno: Centrum pro studium demokracie a kultury, 2012. 
MALÍŘ, Jiří. Nacionalizace obecní samosprávy a limity demokratizace komunální politiky před rokem 1914 na př́kladu Moravy. In: PEŠEK, Jiří - LEDVINKA, Václav (eds.). Mezi liberalismem a totalitou. Sborník př́spěvků z konference Archivu hlavního města Prahy 1994. Praha: Archiv Hlavního města Prahy, 1997, pp. 73-93.

MALÍŘ, Jiří. Obecní samospráva a národnostní problematika na Moravě před rokem 1914 (deset poznámek k „boji o radnice“ moravských měst). In: VALENTA, Edvard (ed.). Národnostní problémy v historii měst. Prostějov: Muzeum Prostějovska, 1993, pp. 75-87.

MALÍŘ, Jiří. Samospráva jako prostředek poslanecké kariéry. In: FASORA, Lukáš - HANUŠ, Jiří - MALÍR̆, Jiří (eds.). Občanské elity a obecní samospráva 1848-1948. Brno: Centrum pro studium demokracie a kultury, 2006, pp. 152-164.

MAREK, Pavel. Prostějov v moravské politice na přelomu 19. a 20. století. K problematice souvislostí bojů o český Prostějov v letech 1890-1892 s česko-německými smiřovačkami a moravským paktem z roku 1905. In: VALENTA, Edvard (ed.). Národnostní problémy $v$ historii měst. Prostějov: Muzeum Prostějovska, 1993, pp. 14-19.

MATES, Pavel - SCHELLE, Karel. Ke vzniku Velkého Brna. In: Forum Brunense, 1992, pp. 107-116.

MATES, PAVEL. Obecní volby v roce 1919, jejicj průběh a výsledky v Brně. In: Časopis Matice morauské, 1979, vol. 98, pp. 3-31.

MILLER, Paul - MORELON, Claire (eds.). Embers of Empire. Continuity and Rupture in the Habsburg Successor State after 1918. New York: Berghahn, 2018.

MORELON, Claire. State Legitimacy and Continuity between the Habsburg Empire and Czechoslovakia: The 1918 Transition in Prague. In: MILLER, Paul - MORELON, Claire (eds.). Embers of Empire. Continuity and Rupture in the Habsburg Successor State after 1918. New York; Oxford: Berghahn Books, 2019, pp. 43-63.

Österreichisches Biographisches Lexikon 1815-1950. Vol. 12. Wien: VÖAW, 2005.

PALÁNOVÁ, Alena. Česko-německé vztahy na národnostně smíšeném území Jihlavska v letech 1919-1925. In: Vlastivědný sborník Vysočiny, 2000, vol. 12, pp. 117-131.

PALÁNOVÁ, Alena. Vznik československé republiky a události na národnostně smíšeném území Jihlavska. In: Vlastivědný sborník Vysočiny, 1998, vol. 9, pp. 211-233.

PALÁNOVÁ, Hana. Poslanci Moravského zemského sněmu za okresy Jihlava a Třebič v letech 1861-1914. Master's thesis, Masaryk university, 2010.

PEŠA, Václav. Národní výbory v českých zemích roku 1918. Praha: ČSAV, 1962.

PEŠA, Václav. Národní výbory v roce 1918 na Moravě a ve Slezsku. In: Časopis Matice moravské, 1958, vol. 77, pp. 249-289.

PEŠEK, Jiří. Vznik, charakter a konec první Československé republiky (Několik úvah k aktuálním diskusím). In: Český časopis historický, 2018, vol. 116, no. 3, pp. 659-692.

PÍSKOVÁ, Renata (ed.). Jihlava. Historie - kultura - lidé. Praha: Nakladatelství Lidové noviny, 2009.

POKLUDOVÁ, Andrea. Änderung in der Stadtverwaltung nach dem Ersten Weltkrieg in Troppau und Olmütz. In: CORNELISSE, Christoph - PETRBOK, Václav - PEKÂR, Martin (eds.). Stadt und Krieg im 20. Jahrhundert: neue Perspektiven auf Deutschland und Ostmitteleuropa. Essen: Klartext, 2019, pp. 87-112.

POPELKA, Petr. Mocenský transfer, boj o radnice a problém slučování obcí po první světové válce: Příklad národnostně smíšené oblasti Zábřežska. In: Časopis Matice moravské, 2018, vol. 137, pp. 87-111.

POPELKA, Petr. Podnikatel jako národní agitátor. Hermann Brass a jeho aktivity při sčítání lidu na Zábřežsku v letech 1900-1930. In: Časopis Matice moravské, 2016, vol. 135, pp. 4167.

POPELKA, Petr. Proces české národní aktivizace na severozápadní Moravě do první světové války. In: Historica Olomucensia, 2019, vol. 57, pp. 103-136.

POSPÍCHAL, Miroslav. Olomouc v době vzniku CSR. In: Střední Morava, 1968, vol. 2, pp. 24-31.

PRZYBYLOVÁ, Blažena (ed.). Ostrava. Historie - kultura - lidé. Praha: Nakladatelství Lidové noviny, 2013. 
RANDÝSEK, Robert. Jihlavský národní výbor v roce 1918. In: Časopis Matice moravské 1964, vol. 83, pp. 205-211.

ŘEPA, Milan. Moravané nebo Češi? Vývoj českého národního vědomí na Moravě v 19. století. Brno: Doplněk, 2001.

RUMPLER, Helmut - HARMAT, Ulrike (eds.). Die Habsburgermonarchie 1848-1918. Band XII. Bewältigte Vergangenheit? Die nationale und internationale Historiographie zum Untergang der Habsburgermonarchie als ideelle Grundlage für die Neuordnung Europas. Wien: Verlag der Österreichische Akademie der Wissenschaften, 2018.

RUMPLER, Helmut - URBANITSCH, Peter (eds.). Die Habsburgermonarchie 1848-1918 VII. Verfassung und Parlamentarismus 2. Die regionalen Repräsentativkörperschaften. Wien: Verlag der Österreichische Akademie der Wissenschaften, 2000.

SCHELLE, Karel. Vznik Československé republiky a státní správa. In: Práuněhistorické studie, 1990, vol. 31, pp. 5-42.

ŠEDIVÝ, Ivan. K otázce kontinuity nositelů státní moci. Jmenování vedoucích úřredníků v kompetenci ministerstva vnitra v letech 1918-1921. In: KOSTRBOVÁ, Lucie (ed.). Moc, vliv a autorita v procesu vzniku a utváření meziválečné ČSR (1918-1921). Praha: Masarykův ústav AV ČR, 2008, pp. 189-196.

ŠERKA, Jozef. Úřad spojené správy. Pokus o částečné administrativní spojení Ostravska a Těšínska v letech 1918-1919. In: Ostrava. Sborník k dějinám a současnosti Ostravy a Ostravska, 2019, vol. 33, pp. 192-206.

SVĚRÁK, Vlastimil (ed.). Nikdy zcela neodešli: Jihlavští Němci / Sie waren nie ganz fort: die Iglauer Deutschen. Jihlava: Státní okresní archiv Jihlava, 2013.

ŠVORC, Peter - HEPPNER, Harald (eds.). Velká doba v malom priestore. Zlomové zmeny $v$ mestách stredoeurópskeho priestoru a ich dôsledky (1918-1929). Graz; Prešov: Universum, 2012.

VELEK, Luboš. Rozvíjení české samosprávy jako náhrada neexistujícího státu a jako předstupně státní samostatnosti. In: FASORA, Lukáš - HANUŠ, Jiří - MALÍŘ, Jiř́i (eds.). Občanské elity a obecní samospráva 1848-1948. Brno: Centrum pro studium demokracie a kultury, 2006, pp. 146-151.

VIKTOŘIK, Michael. Z „bojů o radnice“ moravských měst. Volby do obecních výborů v Litovli na konci 19. století. In: Časopis Matice moravské, 2015, vol. 134, pp. 81-108.

VRÁNA, Filip - SCHELLE, Karel. Vznik velkého Brna. Ostrava: Key Publishing, 2011.

VYKOUPIL, Libor. Brno mezi dvěma válkami. In: BALÍK, Stanislav et al. Lokální politický pluralismus. Brno ve třech stoletích. Brno: Centrum pro studium demokracie a kultury, 2006, pp. 23-36.

VYSKOČIL, Aleš. C. k. úředník v československých službách. In: Časopis Matice moravské, 2006, vol. 125, pp. 425-459. 